\title{
DRAFT OF ACT ON THE MANAGEMENT AND CONTROL OF PUBLIC FINANCES
}

\section{Introduction}

$\mathrm{D}$ raft of Act on the Management and Control of Public Finances (hereinafter "the Draft") should replace the existing Act no. 320/2001 Coll., on Financial Control in public administration and amending certain acts (Financial Control Act), as amended. The Draft represents the $\mathrm{x}$-th attempt of reform the system of control and internal audit of public finances in Czech Republic.

In accordance with the Legislative Rules of the Government the Draft with accompanying materials was sent to comment procedure on 22 July 2015 with the date of comments delivery by 25 August 2015. The comment procedure involved over 100 of commenting organization from public sector, including the Union of Towns and Municipalities of the Czech Republic ${ }^{1}$ and the Association of local self-governments ${ }^{2}$. From the deadline for applying comments until March 2016 Ministry of finance led meetings and consultations with the commenting organizations. The material has been modified based on comments from the comment procedure. Almost all comments were settled without contradictions. Subsequently the Ministry of Finance realized legislative-technical modifications. The Draft was submitted for consideration of the Government Legislative Council on 12 May 2016. Currently, the Ministry of Finance is incorporating comments of Legislative Council. Further legislative process will continue in the Government and the Parliament. The Act is proposed to be effective from $1^{\text {st }}$ January 2018.

\section{Unifying of management and control system}

A key proposed change is the revision of the whole system of management and control of public finances. Currently in approving expenditures or entering into a contract two processes coexist. One process is administrative implemented in organization only to satisfy the requirements of the Act on financial control and the other, real approval process that reflects the needs of each organization. The Draft should unify and simplify these processes. Every public sector organization will be able to set own system to suit it needs, whether it is a ministry, or kindergarten.

One of the objectives that the Draft aims at simplifying the current system of management and control of public revenues and public expenditures, especially with regard to the existence of a large number of small organizations, i.e. the smallest municipalities and subsidized organizations for which it is often existing legislation inapplicable, respectively its application in practice is an unnecessary and unjustified administrative burdens. The Draft does not ensure that control processes will not be formal and will be an effective mean of public finances protection. Adoption of the Draft is only a necessary starting point. A precondition for the successful implementation and realization of a genuine reform of the management and control of public finances is a consistent and active providing methodological support of the Ministry of Finance, namely the Central Harmonization Unit. Function 
of the Central Harmonization Unit together with the Draft should create effective system of protection of public finances.

\section{The main changes}

In order to simplify the existing system, the Draft introduces a major change in the performance of management and control at the expenditure and revenue operations. The Draft clearly establishes that economic control will be carried out only in operations that the organizations may affect. This adjustment is to eliminate the current practice, when the proofs of control of revenue operations are produced even when it is casual income, which becomes municipal budget revenue without any intervention of the municipality. For example entitled to the income arises from the act.

Furthermore, the Draft allows that in small organizations, economic control can be provided by a person who is not an employee. Today the Financial Control Act strictly provides that the function of budget administrator and main accountant can be performed only by an employee of the municipality. This is inapplicable especially in the smallest villages or kindergartens. It is normal that with regard to the principle of economy, efficiency and effectiveness, the economic agenda is outsourced by a person with Trade Certificate. However, because of the current provisions of the Act on Financial Control, this person must have employment agreement with the municipality.

With regard to practical experience with the performance of management and control in the smallest villages, Ministry of finance does not insist that the operations should be approved by a senior employee in these cases. In the village with unreleased mayor, where a number of activities is provided by unreleased members of municipal council, it is not practical, nor cost-effective to insist that the principal function of the operation should be held by employee, let alone a senior employee. Therefore, the Draft allows the approver function can be held by the deputy mayor or a member of the Control Committee of the council. The reason that the content of the mentioned function is changing significantly by the Draft, it is necessary to change also the terminology. Changing of the terminology is often criticized by the municipalities.

\section{Principles of the Draft}

Principles of the Draft are economical, effective and efficient public finance management and control, principle of proportionality and single audit approach.

Definition of economical, efficient and effective management of public finances is already contained in the Act on Financial Control. The Draft clarifies the definition and creates tools for the implementation of these principles in practice. One of these tools is the preliminary assessment of expenditure operations. In terms of legal status it is an entirely new institution, however, many public authorities have already established the institute in the decision-making processes. There can be demonstrated that the objective of the Draft is not to introduce new bureaucratic obligations, but rather its aim is to share the good practice across all public authorities.

Preliminary evaluation of expenditure operations represents control during first phase of decision making. Its object should be to assess the needs to be met through public funding and its variants of satisfaction. For example this may include an assessment of whether the municipality will rent its office or purchase a building for it. Further evaluation of operating costs in the years following the implementation of the investment for a minimum period of sustainability should be an important part of preliminary assessment evaluation. For example these include grant programs to support employment, from which you can pay the cost of repairing of properties. From the beginning, the subsidy seems to be convenient and easy money gained. However, if before applying for a grant municipality do not calculate how much operating costs will increase, the municipality may be unpleasantly surprised.

One of the major problems which the Ministry of Finance had to deal with is the fact that, as the Financial Control Act and the Draft turns out to thousands of organizations of different sizes and with different organizational structures. Addressee is organization such as the Ministry of 
Defense as well as the kindergarten set up by municipalities. Therefore, the Draft gives organizations flexibility in determining the value and type of expenditure operations, for which the preliminary assessment will be carried out. It is a manifestation of the principle of proportionality. The principle of proportionality pervades the entire Draft.

One of the other manifestations of principle of proportionality is the criteria for mandatory establishment of internal audit. Today an internal audit must be established by all municipalities over 15,000 populations. In the future, the population has to be only one of the conditions. Another criterion is the size of the budget, for example, the volume of subsidies provided or the number of employees. Internal audit is an important tool to protect public finances. However, to be truly effective, it is essential to be adequately staffed. Therefore, it makes no sense to establish an internal audit unit, where the cost of ensuring its functioning (particularly wages and training costs) are greater than the risks to be treated this way. Internal audit, which is secured by a single worker, whose primary job is to provide a public service, does not have the necessary added value. In practice, for example, the high school teacher who is still at 0.1 time charged with the performance of internal audit. In this case, it is only a formal fulfillment of the provisions of the Act on financial control and, as such, unfounded.

The essential principle of the new legislation should be single Audit principle. The essence of this principle is that the authorities responsible for control and audit shares the results of their activities, these results are so good that they can rely on and therefore it does not control or audit performed again. The purpose is to remove duplicate checks. The Draft creates the necessary prerequisites. Together with the existing information system of the Ministry of Finance this sharing is possible. Obviously methodological assistance, particularly to ensure the required quality of output control and audit authorities, is a necessary.

\section{Conclusions}

Finally, it is important to emphasize that the Draft does not interfere with the constitutionally guaranteed rights of municipalities to self-government. The management and control mechanisms and internal audit, that matter contents of the Draft, do not interfere with decision-making powers of local authorities of the municipality,

i.e. council and assembly. The Draft sets out the minimum requirements for the preparation of materials for meetings of the council or assembly. Approval of expenditure operations in the economic control process does not bind the council or assembly to make the expenditure or enter into a contract. It remains a sovereign right of self-governing municipal bodies. Defined minimum requirements for the preparation of materials contribute to greater awareness of the institutions that are authorized to make decisions and have the relevant responsibility for their decisions.

\section{$\underline{\text { Abstract }}$}

The article deals with the draft of Act on the Management and Control of Public Finances which is nowadays prepared by Ministry of Finance of Czech Republic. It is an important act of management and control of public budgets. The article presents the positive changes of the public finance management system for the municipalities. In the Czech Republic there are more than 6000 municipalities. Many of them are too small to have appropriate personal resources to ensure the adequate control of public finance. The draft tries to simplify the system to helps the smallest municipalities and to ensure the minimum level of the public finance protection.

Union of Towns and Municipalities of the Czech Republic is a voluntary, apolitical and non-governmental organization founded as an interest group of legal entities. Members of the Union are towns and municipalities. The Union associates approximately 2,500 municipalities and towns. They represent more than $70 \%$ of the total population of the Czech Republic.

2 Association of local self-governments is a voluntary, apolitical and non-governmental organization founded as an interest group of legal entities. Members of the Union are towns and municipalities. The Union associates approximately 1,100 municipalities and towns. 